11. Zavarika, H. M. (2021). Suspilno-heohrafichnyi vymir post konfliktnoho rozvytku turyzmu na prykladi skhidnykh terytorii Ukrainy: avtoref. dys. ... kand. heoh. nauk. Lutsk, 20 p. (in Ukrainian).

Матеріал надіймов до редакиії 17.01. 2021 p.

УДК: (438) “18/.19” : 070

Марія Павлюх,

кандидат наук із соціальних комунікацій, асистент, Національний університет «Львівська політехніка», ORCID ID 0000-0001-5502-8367

mariia.v.pavliukh@lpnu.ua

DOI 10.29038/2524-2679-2021-01-324-333

\title{
ГРОМАДСЬКА ТА ПОЛІТИЧНА ДІЯЛЬНІСТЬ ЖІНОК У ГАЛИЧИНІ КРІЗЬ ПРИЗМУ АЛЬМАНАХІВ НАТАЛІ КОБРИНСЬКОЇ
}

У статті висвітлено важливий історичний етап у Галичині - боротьбу активних жінок за свої громадянські та політичні права. Активною формою боротьби жінок стала журналістська діяльність, публіцистична та літературна творчість у неперіодичних виданнях - альманахах, які видавала відома активістка Наталя Кобринська. Простежено боротьбу жінок за свої права крізь призму альманахів Наталі Кобринської. Досліджено історію видання альманахів Наталі Кобринської. Виокремлено жіночі альманахи як периий етап розвитку жіночої політичної преси в Галичині. Доведено, щзо жіночі альманахи - перші неперіодичні (із невизначеною періодикою) видання, у яких поширювались ідеї емансипації. Проаналізовано структуру, зміст та статті активних жінок, які порушували перед громадськістю та суспільством актуальні проблеми українського жіноцтвва.

У дослідженні проведено грунтовний аналіз тематичного та проблемного контенту жіночих альманахів. Завдяки описовому методу дослідження здійснено компаративний аналіз жіночих альманахів та виокремлено їхній громадсько-політичний характер. Відстежено тендениії розвитку українського жіночої руху в Галичині як форму громадянськоӥ й політичної боротьби украӥнської жінки за свої права. 3'ясовано, щуо громадянська та політична діяльність жінок розвивалась у загальній тенденції боротьби української нації за власне самовизначення.

(C) Павлюх М., 2021 
У науковій статті проаналізовано загальні тенденції розвитку активного політичного й громадського жіночого руху в країнах Європи та украӥнського жіночого руху як його важливої компоненти. З'ясовано що украйнський жіночий рух, жіночі неперіодичні (альманахові) видання й жіноча періодика активно розвивалися за європейськими традиціями. Установлено, що жіночі неперіодичні видання - альманахи - були зразками політичної жіночої літератури, котра стала передвісником політичної жіночої періодики.

Ключові слова: політична діяльність, громадянські права, емансипація, жіночі альманахи, жіночі права, жіноча періодика.

\section{1. ВСТУП}

Жіноча альманахова література, яка виникла 3 поширенням ідеї емансипації, становила перший етап розвитку жіночої періодики. Література для жінок і про жінок, написана жінками, відкривала новий погляд на жіноче питання, новий погляд на жінку. Досі в літературі панівне місце займали чоловіки, які нав'язували своє бачення жіночих проблем i жіночої долі. Жінки за невеликими винятками не мали можливості розповісти про себе, про своє відчуття, про свою нелегку долю, а тим паче боронити свої особисті права й добиватися рівноправності. Жінкигаличанки, на жаль, не могли користуватися тими правами, що жінки Наддніпрянської України чи західноєвропейські жінки.

Принизливе становище галицької жінки, застарілі стереотипи про роль жінки в суспільстві, боротьба української інтелігенції за права своєї нації спонукали свідомих жінок-інтелігенток вести пропаганду, просвітництво, активну громадську й політичну діяльність серед сільського жіноцтва. Жінки були позбавлені можливості вчитися в університетах, а здобути домашню освіту могли лише аристократки. Ці причини спонукали Наталю Кобринську, активну громадську діячку, створити на Галичині першу жіночу організацію, видавати жіночі альманахи, щоб пробудити дух української жінки, щоб підготувати жінку до глибшого розуміння своєї ролі в суспільстві та державі, нового бачення жінки, не тільки дружини й матері, але й свідомої патріотки, жінки-громадянки, яка відповідальна за свій народ та майбутні покоління.

Постановка проблеми. Вивчення жіночих альманахових видань Наталі Кобринської важливе для висвітлення діяльності жіночих товариств у Галичині, активної громадської та політичної діяльності українського жіночого руху. 
Мета наукової статті - дослідити громадську й політичну активність через вивчення жіночих альманахів; детально розглянути структуру видань, тематичний контент жіночих альманахів та простежити загальні тенденції розвитку українського жіночого руху в Східній Галичині.

Методика дослідження. У науковій статті використано хронологічний та історичний науковий підходи, а також методи аналізу (аналіз тематики жіночих альманахових видань), синтезу (тематичний контент), компаративного аналізу (порівняльні критерії жіночих альманахових видань).

\section{2. РЕЗУЛЬТАТИ ДОСЛІДЖЕННЯ}

У XIX ст. в Східній Галичині починають поширюватись ідеї емансипації. Як зазначає С. Сфремов у своїй праці, «Галицька громадськість змушена була звернути увагу на питання, пов'язані із суспільним становищем жінки, оскільки через усілякі чужі впливи, переважно польські та німецькі, жіноцтво в інтелігентному товаристві займало там особливе становище, принадне, на перший погляд, тяжке і образливе по суті» [6, с. 211]. Галичанка була позбавлена тих можливостей, якими користувалися жінки в Наддніпрянській Україні. Скажімо, літературознавець М. Деркач наголошує на тому факті, що Леся Українка, переїжджаючи через Галичину, уже в 90-х роках XIX ст. жахнулася звичаїв галицького суспільства щодо жінки й назвала це азіатством. Принизливе суспільне ставлення до жінки викликало незадоволення в багатьох жінок, особливо з інтелігентної верстви. Деякі з них почали відверто відстоювати свою позицію, спрямовану на рівноправність із чоловіками в суспільному та політичному житті.

Жіночий рух охопив західноукраїнські землі, які перебували в кінці XIX ст. в складі Австро-Угорської імперії. Піонером жіночого руху була громадська діячка й письменниця Наталя Кобринська. Вона заснувала в Станіславі (сучасний Івано-Франківськ) «Товариство руських женщин» та сприяла появі альманаху «Перший вінок» 1887 р. Н. Кобринська - перша громадська активістка на західних землях, яка висунула ідею жіночого часопису, щоправда, літературно-наукового, із трактуванням жіночого питання. На жаль, через матеріальні проблеми світ не побачив цей часопис.

Зараз постає кілька важливих запитань: чи можна альманахи Н. Кобринської вважати політичною періодикою, адже альманахи - видання неперіодичні, i друге - чому ці альманахи вважаємо передвісниками справжньої української преси для жінок. Такі питання важливі для 
дослідження еволюції жіночої преси в Галичині.

Пожвавлення альманахової літератури можна пояснити австрійським законом, за яким кожне періодичне видання підлягало подвійній цензурі - поліції та прокуратури. А видання неперіодичне обсягом понад п’ять сторінок цензурі не підлягало. Але цей закон не дає чіткого пояснення того, чому деякі науковці відносять альманахи до періодики, бо альманахи - явище літературне, а не журналістське. Відповідь на це питання знаходимо серед статей В. Передирій, яка виокремлює ознаки альманахів, подібних до пресових: «альманахи мають ряд журнальних ознак: м’яку обкладинку, наявність публіцистичних публікацій та коментарів, некрологів» [5, с. 45]. Крім того, альманахи відіграли важливу роль у Галичині: вони замінювали журнали, заповнювали прогалину в літературно-мистецькому процесі.

I. Франко називав альманах «Перший вінок» невеликою книгою. У виданні взяло участь 12 авторок. М. Возняк описує, як Н. Кобринська збирала матеріал для свого альманаху, до якого залучила О. Косачеву як помічницю. Авторки присилали до редакції свої доробки. Г. Барвінок прислала до альманаху свою повість, за яку не вимагала ніякої плати. Молода тоді Леся Українка надрукувала в «Першому вінку» твір «Русалка».

В. Дмитрук у «Нарисі з історії української журналістики ХІХ століття» згадує про розбіжності авторів «Першого вінка»: «Згодом коштом Наталі Кобринської та Олени Пчілки був виданий альманах "Перший вінок" 1886 р. Але дві його видавниці відрізнялися між собою у політичних поглядах. Олена Пчілка належала до ліберального табору, а Наталя Кобринська швидше до демократичного табору» [1]. І. Франко виділяє одну статтю 3 публіцистики Н. Кобринської «Замужні жінки серед багатої верстви», де авторка реалістично показує скрутне становище жінки. Саме ця стаття дає підстави вважати Кобринську демократичною журналісткою та публіцисткою.

У видавничій жіночій справі важливу роль відіграв М. Павлик, який цікавився жіночим питанням. Він протестував проти жорстокого поводження 3 жінкою: «Павлик займався жіночим питанням 3 самого початку своєї громадсько-літературної діяльності, читав літературу з питань жіночої емансипації. Першою людиною, яка зацікавила Павлика жіночим питанням, був М. Драгоманов, який гостро виступав проти поневолення жінок, пропагував ідеї жіночої рівноправності з чоловіками» [1].

М. Павлик пише низку творів, де головною героїнею твору є знедолена жінка. Вражає своїми конфліктами його оповідання «Робенщукова 
Тетяна», у якому розповідається про трагічний конфлікт людини (жінки) й усталених стереотипів-поглядів суспільства на жінку. До «Жіночого альманаху» Павлик подав оповідання своєї сестри Ганни «Зарібниця» та статтю другої сестри Катерини про стосунки між молоддю на Косівщині. Разом із нею написав оповідання «Сам собі». М. Павлик не лишався осторонь від появи альманаху «Перший вінок». Він написав кілька рецензій на жіночі твори. Відомою рецензією на «Перший вінок» стала стаття «Перші ступні русько-українського жіноцтва», у якій автор писав про важке життя жінок на селі.

Інтерес до жіночого питання зростав. Коли Н. Кобринська повідомила Франкові, що вирішила видати альманах власним коштом, оскільки посварилася 3 «Товариством», I. Франко написав дискусійну статтю «Альманах чи газета?» Він виступив з ідеєю видання жіночої газети, котра б принесла більше користі, аніж альманах.

Наміри публікувати наступне після «Першого вінка» жіноче видання мала Леся Українка, яка уважно стежила за розгортанням «жіночого питання» в Галичині й розвитком цієї преси. У жовтні 1891 р. М. Павлик повідомляв Лесю Українку про жіночий альманах, котрий збираються видавати галичанки. Невдовзі, поетеса написала своєму адресату про власне розуміння жіночої газети, вважаючи, що журнал може забезпечити більшу систематичність і поетапність. Леся Українка відзначала, що жіночий рух у Галичині тісно пов'язаний із політичними рухами і не може самостійно розвиватися.

Утілення в життя цих намірів виявилося складним і тривалим процесом, хоча поетеса пам'ятала свою ідею. 11 лютого 1892 р. вона пише дядькові М. Драгоманову: «Нема тяжчої і маруднішої роботи як робота українського публіциста, i, приступатись до неї треба з міцною головою та твердою вдачею» [2, с.21]. Слова Лесі Українки стосуються видання газети для жінок. Пізніше вона писала дядьку на тему «жіночого питання», але згадувала про свої розходження в поглядах iз Н. Кобринською на видання й висвітлення жіночої квестії. Поетеса вважала тему «Жінка-українка і їі діяльність на полі національного відродження» трохи незрозумілою; із сумнівом поставилася до проєкту «Дрібної жіночої бібліотеки», засудила сепаратизм в описі фактів із життя та жіночої психології.

Власні погляди вирізняли Лесю Українку в розмежуванні поняття жінки-письменниці чи критика. У листі до О. Маковея вона однозначно не погоджувалась у розмежуванні критика дівочих чи чоловічих творів. А в листі до О. Кобилянської 17-18 травня 1899 р. обурено повідомляла 
про приниження в Галичині жінки й псевдосприяння поступовців «жіночому питанні». Ці дві активні громадські та політичні діячки в літературі пробували порушити «домінуючу чоловічу традицію», тому що пов'язали модерну літературу з емансипацією, увели нові мотиви, образи й створили тип «нової жінки». Цікаво, що галицькі поступці прислухались до «жіночого голосу». 3 одного боку, підтримували жіночі видання, вітали творчих письменниць (І. Франко, О. Маковей, І. Павлик), 3 іншого - не могли позбутися страху чоловіків перед фемінізмом і широкими жіночими правами.

«Перший вінок» побачив світ 1886 р., але він мав продовження. 1893 р. Н. Кобринська підготувала ще один альманах - «Наша доля» (другий - 1895 р., третій - 1896 р.), а опісля започаткувала альманах «Жіноча бібліотека», де були опубліковані твори, художні й публіцистичні, Є. Ярошинської, М. Ревакович, Г. Барвінок. Українське жіноцтво вийшло за межі рутинних господарсько-родинних обов'язків і здобуло собі гідне місце в суспільстві. Жіноча альманахова традиція дала змогу виявити себе не тільки на освітньо-культурній ниві, а й позмагатися з чоловіками в письменницькому хисті.

Альманахи Кобринської стали цікавим громадським, політичним i літературно-журналістським явищем. У передмові до книги «Українські літературні альманахи та збірники XIX століття» альманахи розглядаються частиною літературного процесу XIX - початку XX ст.: хоча альманахи були виданнями неперіодичними, вони замінювали періодичні.

Якщо детально розглянути зміст альманаху «Перший вінок», то можемо простежити, що він (альманах) великий за розмірами (464 сторінки). Перші три сторінки - вступна стаття самої упорядниці Н. Кобринської «Попереднє слово». Далі - ïi стаття про жіночий рух та перспективи розвитку «Про рух жіночий в ювілейних часах», яка порушує важливі політичні проблеми галицького краю. Далі журналістські жанри змінюють художні твори Уляни Кравченко (сонети «Я не жалюсь»), оповідання Г. Барвінок та твір Лесі Українки «Русалка».

Цікавою й змістовною $є$ стаття Кобринської «Руське жіноцтво в Галичині в наших часах», у якій авторка висловлює власне бачення жінки як особистості. Багатий альманах не лише на жанри художньої літератури та журналістики, а й публіцистики. Він має цікаві нариси про жінок-сподвижниць, зокрема нарис Н. Кобринської «Пані Шумінська», Л. Старицької - «Людмила Панахида». Хоча ці праці тяжіють до художніх жанрів, однак описують документальні події й мають реальних 
прототипів. Ольга Франко надрукувала статтю «Карпатські бойки та їх родинне життя». Оповідання О. Пчілки «Товаришки», оповідання Г. Павлик «Зарібниця» (образ із жіночого життя) вражають своїми гострими політичними конфліктами.

«Перший вінок» можна назвати документальним життєписом жіночого руху. В альманасі надруковані поезії, сонети, інформаційнонаукові статті та оповідки-нариси (про життя жінки, яка має реального прототипа в житті). У наступних альманахах Кобринська продовжила жіночу справу. Три видання альманаху «Наша доля», які вийшли згодом, були продовженням жіночої теми, жіночого питання. Але вони значно менші за обсягом, об'єднували твори українських письменниць та їхні наукові праці. У першому виданні 1893 р. альманах відкривався вступною статтею Н. Кобринської «Жіноча справа в Галичині», у якій розповідалося про феміністичний рух і його поступ. Інформаційна замітка Г. Грималюк «Промова селянки з села Тишіївки Городенського повіту» - промова неписьменної жінки в обороні прав сільського жіноцтва. В альманасі з'являється інформаційна рубрика - «Звістки 3 краю». Друге та третє видання «Нашої долі» містило кілька статей про жіночий рух, твори й праці зарубіжних авторів (Гете, Міллера, Гейне, Байрона). У кінці альманахів опубліковано заклики до жінок передплачувати видання «Жіноча бібліотека».

Альманахи Н. Кобринської були цікавим політичним і громадським явищем на західноукраїнських землях. Вони вперше поставили жіноче питання як проблему. Альманахи мають наявні ознаки періодичних видань, тому що статті тяжіють до інформаційно-наукових. На думку самої Наталі Кобринської, «історичну вартість жіночого альманаху складають, непоодинокі його праці, але той факт, виявлений цілим його складом, що жіноцтво наше на цілім просторі широкої Руси-України почулося до свого існування народного, що інтелігентна жінка наша почулася одночасно русинкою і чоловіком, дбала о свої права національні і громадські - факт радісний з погляду суспільного і історичного. Підняти себе, свої народні, громадські права і обов'язки - не заслуга, а обов'язок людини» [4, с. 35].

Чи можна вважати видання Кобринської лише літературним, журналістським явищем, чи громадсько-політичним? Велика кількість художніх творів указує на мистецьку вартість альманахів Н. Кобринської. Проте публіцистична частина альманахів указує на те, що Кобринська хотіла вивести альманахи за межі літературної книжки та надати ій рис публіцистики - статті на тему жіночого питання, тобто політичної 
періодики. Власне, задуми Кобринської щодо жіночого видання, у котрому б містилися «серйозні» рубрики, сягав замірів періодичного. Альманахи Кобринської можна назвати виданнями «журнального типу», бо вони містять низку подібних ознак до періодичного видання. Виходили альманахи Кобринської серійно, а отже, можуть претендувати на роль періодичних (простежується певна періодичність). Структура альманахів складалась із вступної редакційної статті, публіцистичної та літературної частин.

Отже, крізь призму жіночої альманахової періодики здійснювалась активна громадсько-політична діяльність жіночих організацій.

\section{3. ВИСНОВКИ ТА ПЕРСПЕКТИВИ ПОДАЛЬШИХ ДОСЛІДЖЕНЬ}

У своїх альманахах Н. Кобринська намагається донести до жіноцтва ідею активної громадської діяльності небайдужих жінок, що творять для своєї батьківщини, плекають рідну мову, дбають за свої звичаї. Альманахи Кобринської об'єднували свідомих жінок-патріоток, емансипованих жінок, які намагалися змінити традиційні уявлення про роль жінки в суспільному житті та надати жінці новий образ. Альманахова література Кобринської заклала початок жіночої періодики в Галичині й активному політичному визвольному руху української нації. Досвід активної політичної діяльності жіноцтва в XIX ст. важливе для нашого сьогодення.

\section{СПИСОК ВИКОРИСТАНИХ ДЖЕРЕЛ}

1. Возняк, М. (1908). Як дійшло до першого жіночого альманаху. Львів, с. 38 (in Ukrainian).

2. Передирій, В. А. (2002). Календар-альманах як тип періодичного видання (за матеріалами галицької преси 20-30-х рр. ХХ ст.). Українська періодика: Історія та сучасність. Львів, с. 526-529 (in Ukrainian).

3. Франко, I. (1984). Українська альманахова література: зб. творів: у 50 т., т. 27. Київ, с. 107 (in Ukrainian).

4. Франко, I. (1984). Альманах чи газета: зб. творів: у 50 т., т. 28. Київ, с. 197 (in Ukrainian).

5. Русова, С. (1934). Намі визначні жінки: літературні характеристики і силуети. Вінніпег, 92 с. (in Ukrainian).

6. Передирій, В. (1995). Галицька періодика для жінок: становлення, розвиток, проблематика (1853-1939рр.). Збірник пращь науково-дослідного центру періодики, вип. 2. Львів, с. 44-63 (in Ukrainian). 


\section{PUBLIC AND POLITICAL ACTIVITIES OF WOMEN IN HALYCHINA THROUGH THE PRISM OF NATALIE KOBRINSKY'S ALMANAHS}

The article is devoted to highlighting an important historical stage in Galicia - the struggle of active women for their civil and political rights. An active form of women's struggle was journalistic activity, journalistic and literary work in non-periodical editions' almanacs, published by the famous activist Natalia Kobrynska. The struggle of women for their rights has been traced through the prism of Natalie Kobrynsky's almanac. The history of the publication of Natalie Kobrynsky's almanacs is investigated. The women's almanacs were singled out as the first stage in the development of the women's political press in Galicia. It is proved that women's almanacs are the first non-periodical (with indefinite periodicals) publications in which the ideas of emancipation spread. The structure, content and articles of active women who have raised urgent problems of Ukrainian womanhood before the public and society are analyzed.

The study conducted a thorough analysis of the thematic and problematic content of women's almanacs. Due to the descriptive method of research, a comparative analysis of women's almanacs was carried out and their sociopolitical character was distinguished. The trends of the Ukrainian women's movement in Galicia as a form of civil and political struggle of the Ukrainian woman for their rights are monitored. It was found that women's civic and political activities developed in the general tendency of the Ukrainian nation's struggle for self-determination.

The scientific article analyzes the general tendencies of the development of active political and social women's movement in the countries of Europe, and the Ukrainian women's movement as its important component. It is found that the Ukrainian women's movement, women's non-periodic (almanac) publications and women's periodicals were actively developing according to European traditions. It is established that women's non-periodical editions - almanacs were models of political women's literature, which became a harbinger of political women's periodicals.

Key words: political activity, civil rights, emancipation, women's almanacs, women's rights, women's periodicals.

\section{REFERENCE}

1. Voznyak, M. (1908).Yak diyshlo do pershoho zhinochoho al'manakhu. L'viv, p. 38. 
2. Peredyriy, V. A. (2002). Kalendar-al'manakh yak typ periodychnoho vydannya (za materialamy halyts'koyi presy 20-30-kh rr. XIX st.). Ukrayins'ka periodyka: Istoriya ta suchasnist'. L'viv, p. 526-529.

3. Franko, I. (1984). Ukrayins 'ka al'manakhova literatura: Zb. Tvoriv: u 50 t., t. 27, Kiev, p. 107.

4. Franko, I. (1984). Al'manakh chy hazeta: Zb. Tvoriv: u 50 t. T. 28. Kiev, p. 197.

5. Rusova, S. (1934). Nashi vyznachni zhinky: Literaturni kharakterystyky i syluety. Vinnipeh, $92 \mathrm{p}$.

6. Peredyriy, V. (1995). Halyts'ka periodyka dlya zhinok: stanovlennya, rozvytok, problematyka (1853-1939 rr.). Zbirnyk prats' naukovo-doslidnoho tsentru periodyky, vyp. 2, L'viv, p. 44-63.

Матеріал надійшов до редакиії 13.01.2021 p.

УДК 327(477):314.151]:316.48

\section{Антоніна Шуляк,}

доктор політичних наук, професор кафедри міжнародних комунікацій

та політичного аналізу, декан факультету міжнародних відносин, Волинський національний університет імені Лесі Українки, ORCID ID 0000-0002-5234-0758 antonina.mytko@vnu.edu.ua DOI 10.29038/2524-2679-2021-01-333-344

\section{ТЕНДЕНЦІЇ МІГРАЦІЙНИХ ПРОЦЕСІВ ЯК ЧИННИКА ПІДВЩЕННЯ КОНФЛІКТОГЕННОСТІ}

У статті міграцію населення розглянуто як складний комплексний процес, що досліджується фахівиями багатьох спеціальностей. Зазначено, щяо міграція та безпека пов'язані не лише прямим, а й зворотним зв'язком, тобто безпекові заходи держав впливають на переміщення населення. Основними тенденціями міграцій населення в Україні в період між останнім його переписом у Радянському Союзі в 1989 р. та першим у незалежній Україні у 2001 р. були зниження загального рівня мобільності населення; зменшення інтенсивності міграційних зв'язків із колишніми республіками СРСР; розширення контактів із країнами пострадянського табору; набуття міграиіями більш «сімейного» характеру; поява і розвиток нових

(C) Шуляк А., 2021 